\title{
Was Eve the first femme fatale?
}

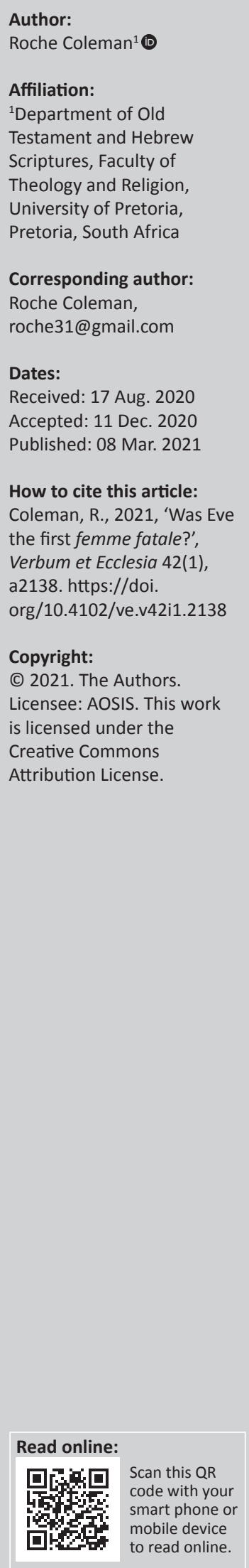

Feminist theology approaches the biblical teaching of the fall with a non-historical or traditional interpretation. The biblical teaching suggests that the primordial couple sinned by eating the forbidden fruit from the tree that God prohibited (Gn 3:1-24). Additionally, the woman is blamed because she functions as a femme fatale who enticed Adam to eat the fruit. Writers within the feminist and non-feminist theology argue that the so-called 'Yahwist' is responsible for a patriarchal view that is evident in Genesis 3. Ultimately, male authors and interpreters of the Bible crafted a narrative that implicated the woman as the culprit for the presence of $\sin$ within humankind. Thereafter, women have been suppressed by the male-dominated culture that has manifested itself throughout the biblical literature. Several approaches seek to absolve the woman of guilt in the fall narrative: firstly, denial of the fall; secondly, depatriarchalising the biblical text; and thirdly, applying a deconstructionist literary methodology. The objective of this study was to consider whether Eve deserves the label of the first femme fatale. Did Eve use influence, beauty and words to persuade Adam to deviate from the divine mandates? The question surfaces uncomfortable considerations, but labelling Genesis 3 as patriarchal is an attempt to silence dialogue. Uncomfortable conversations are essential in the academic quest.

Intradisciplinary and/or interdisciplinary implications: Feminist and non-feminist theologians seek to absolve the woman of the femme fatale label by denying the fall, depatriarchalising the Old Testament and applying a deconstructionist interpretation. This article challenges the feminist, Old Testament and systematic theologian to reconsider their interpretation of Genesis 3, especially, the woman's role as a femme fatale.

Keywords: femme fatale; fall; feminist; patriarchal; deconstructionist.

\section{The femme fatale}

Comparative folklore portrays $\mathrm{Eve}^{1}$ as a femme fatale ${ }^{2}$ (Gaster 1969:22). The nude body of the woman, her unidentified words to the man and his willingness to eat the recommended fruit from the forbidden tree serve as characteristics of a femme fatale (Gn 2:25; 3:6-7). Edwards (2010) made this observation:

Eve offers the fruit to Adam, she makes him a partner - in crime, many would say. Tempting a man is the defining action of the femme fatale: as Webster's definition puts it, she 'leads men into difficult, dangerous, or disastrous situations'. (p. 43)

Apart from the woman's enticing presentation, it is implied that the man would not embark on the uncertain journey with the forbidden fruit that leads to his banishment (Gn 3:17-24).

Eve's alleged seduction of Adam forms a tapestry in the history of folklores, such as the Babylonian Epic of Gilgamesh with the character of Siduri to Calypso who serves as the femme fatale seeking to detain Odysseus in the Greek folk story (Gaster 1969:22). According to Gaster, Genesis does not possess a unique account of the fall of humanity. Rather, the author of Genesis emulates the numerous stories of women serving as femme fatales in the folklore of societies. In his book, Myth, Legend and Custom in the Old Testament, the primeval mother is cast as residing on an 'enchanted island or in some similar domain and as giving succor to the hero on his travels like the woman the Sumerians designated Ninti' (Gaster 1969:22). Ninhursaga created the Sumerian goddess Ninti to heal Enki's rib. Similar to the Eve and Adam eating the fruit in the Garden of Eden, Enki eats forbidden flowers and receives a curse from Ninhursaga. Other deities persuade Ninhursaga to heal Enki of his curse. Ninti was one of eight goddesses who was created for this task and her name

1.As a point of reference, Lilith is the first wife of Adam according to 'The Alphabet of Ben Sira', an anonymous medieval work on passages from the Talmud and Midrash (Stern \& Mirsky 1998:167-202). See Gaines (2019) Lilith: Seductress, Heroine or Murderer for the etymology of Lilith's name. Gaines recommended 'Lilith, lylyt [tylyl] was not derived from the Hebrew word for night, lylh [hlyl], as they supposed. Instead, Lilith's name originated in her depiction as a mythic Mesopotamian friend and foe of Gilgamesh'. See https://www. supposed. Instead, Lilith's name originated in her depiction as a mythic Mesopotamian friend and
biblicalarchaeology.org/daily/people-cultures-in-the-bible/people-in-the-bible/lilith/\#note08r.

2.A femme fatale is an extremely attractive woman who leads men into dangerous situations or causes their ultimate destruction, through mysterious or seductive means that are manipulative (https://dictionary.cambridge.org/us/dictionary/english/femme-fatale). 
represents both 'Lady of the Rib' and 'Lady Who Makes Live' (https:/ /www.brooklynmuseum.org).

Equally, Bailey (1970:143) identified parallels from the primal woman in the Gilgamesh story to the primal woman in the Genesis narrative on creation, but the distinction is that Eve's status is not diminished (Gn 2:1-3:24). In the Gilgamesh epic, Enkidu becomes like a god after he is enticed by the harlot to cohabit for 6 days and seven nights (II.ii11). Bailey (1970:143) described the woman in Genesis as the 'crown of creation'. Furthermore, he states, what is more extraordinary in Genesis is the only account of the creation of woman as such in the Ancient Near Eastern literature. In summary, he notes, whilst the relationship with God is damaged through the woman's disobedience, she receives a splendid status from Yahweh as the first mother. After her punishment, the woman retains her central role that is never achieved by the harlot or any other woman in the Gilgamesh epic. Without question, the Hebrew Bible's account of the fall of the primordial couple and other Ancient Near Eastern literature fit the femme fatale criteria. Biblical interpreters avoid the femme fatale label, but they attribute the femme fatale behaviour to Eve. Charlesworth (2010:306) argued that the labelling of the woman is unfair, and the emergence of Patriarchalism in the Genesis fall account has its origin with the 'Yahwist' ${ }^{3}$ interpretation. Therefore, women are suppressed by the male-dominated culture that manifests itself in the literature. The following comments by authors from the Hellenistic period to the 20th century are noteworthy.

\section{Eve the temptress: Third century to modern interpreters ${ }^{4}$ Apocrypha and Pseudepigrapha}

The Jewish and early Christian literature from the thirdcentury BC to the first centuries referenced the woman's role in the fall. Passages in the Apocrypha and Pseudepigrapha ${ }^{5}$ identify Eve as the antecedent of sin in humanity and the distractor of Adam. In 2 Enoch 31:6, the author writes, '[i]n such a form he (serpent) entered paradise, and corrupted Eve. But Adam he did not contact. But on account of (her-Eve) nescience I cursed them' (Charlesworth 2011:154). Enoch absolved the man of responsibility, whilst sin is the consequence of the woman's inordinate desire. In the Life of Adam and Eve: Eve's story of the fall and its consequences (known as Apocalypse of Moses in the Greek version), the author describes Eve as deceiving Adam by offering him the option to become 'as God' (21:3) (Charlesworth 2011:281). After Adam concedes and recognises his nakedness, he exclaims, 'O evil woman! Why have you wrought destruction among

3.The once popular Documentary Hypothesis by Julius Wellihausen that Genesis is comprised of three separate sources (J -Yahwist, E - Elohist and P - Priestly) is referenced by Charlesworth. The theory has been refuted (cf. Archer 1997; Phelan 2005).

4. Women were considered to be property in Ancient Mesopotamia. Reviewing the literature during antiquity would yield the obvious interpretation. Researchers iterature during antiquity would yield the obvious interpretation. Researchers interpreters. The literature written from the third century represents the core beliefs of officials responsible for shaping many doctrines of the church.

5.For additional insights (see Collins 2000; Delcor 1989; Helyer 2002). us! You have estranged me from the glory of God' (21:5-6) (Charlesworth 2011:281).

Pseudo-Philo acknowledged that Adam violated the holy edict of God in the Garden of Eden, which offers a balance approach. However, he places the culpability on Eve, however, for luring her husband into sin: '[b]ut that man transgressed my ways and was persuaded by his wife; and she was deceived by the serpent. And then death was ordained for the generations of men' (Pseudo-Philo 13:89). Adam sinned, but Eve is cast as the femme fatale who lures the unsuspecting man into her web of lies and deception.

\section{Jesus Ben Sirach}

Historical and modern commentators do not identify Eve with the term femme fatale, but her characterisation remains constant. Writers note the negative influence the woman had on the man and blame her for persuading him to defy God. The Hellenistic Jewish scribe, Ben Sira, wrote, '[s]in began with a woman, and because of her we all die' (Sir 25:24). His writings present the woman as the source of her husband's problems. He blames the 'worthless wife' for her husband's 'depression, downcast looks, and a broken heart' (Sir 25:23). Furthermore, just as a 'leaky cistern' should not drip continuously, a worthless wife should not 'say whatever she likes' (Sir 25:25). If the wife 'does not accept' the control of her husband, Ben Sirach recommends the husband to 'bring the marriage to an end'. Why? 'A man's wickedness is better than a woman's goodness; women bring shame and disgrace' (Sir 41:24). Ben Sirach writes during the Second Temple period when the Seleucids controlled Jerusalem. His patriarchal ideology originated under the influence of Hellenistic misogyny (Phipps 1989:53). Phipps credited the second-century Ben Sirach as the initial purveyor of the 'reign of death to a happening in Eden', as well as inciting beliefs that lead to the Judeo-Christian doctrine of the fall. One can only speculate whether it was the culture or the biblical narrative that impacted Sirach's explanation of the woman.

\section{Church fathers}

The writings of the church fathers clearly suggest their view of the woman as possessing femme fatale characteristics. John Chrysostom (1979:435) proposed, '[f]or the sex (female) is naturally somewhat talkative: and for this reason he restrains them on all sides'. Chrysostom (1979:435-436) continued by arguing that (1) the male sex enjoyed the higher honour as man was first formed and thus demonstrates his superiority; (2) women are not permitted to teach because the woman taught the man once, making him guilty of disobedience and bringing the ruin of humanity; (3) God subjected women to men because she was beguiled, a superior was deceived by an inferior, a subordinate animal; and (4) the prohibition against women leading and teaching men is a collective command as the sex (woman) is weak and fickle. 
Likewise, Nazianzen, Schaff and Wace (1994) soundly concurred with Chrysostom writing:

[S] he (the woman) indeed who was given to Adam as a help meet for him, because it was not good for man to be alone, instead of an assistant became an enemy, and instead of a yokefellow, an opponent, and beguiling the man by means of pleasure, estranged him through the tree of knowledge from the tree of life. (pp. 256-257)

Both Gregory and Chrysostom place responsibility on the helper, Eve. (cf. Gn 2:16-17; 3:1-3). Both the man and woman are entrusted with the fiduciary duties of the garden, but the woman reversed course towards a path of deceit. Didymus (2016:83) noted in his commentary on Genesis that the woman compelled the man to aid and abet her with senseless actions. After being enticed, she took the word of the serpent as full consent and ate to bring the unfaithful deed to completion. She also made her husband an accomplice, being guilty herself and making him assist in the deception, such being the sensation that has been described as a block on the woman's reason. Didymus (2016:83) further noted that shameful behaviour stripped them of their virtue, resulting in eyes that previously were beneficially closed to be opened.

\section{Medieval period to protestant reformation}

As writers from successive generations read the fall account, the woman is continuously blamed for enticing the man or possessing an inferior intellect. Saint Augustine of Hippo lived in the pre-Medieval period. Many of his theological interpretations are fundamental to Christian doctrine. Augustine argued that the woman is morally inferior to the man as she is the weaker vessel (cf. Augustine 2009:342-430; Augustine \& Taylor 1982:3-177; 1 Pt 3:7). Basically, he surmised that the serpent selected Eve because she was weak. The argument seems unwarranted since both Adam and Eve were created perfect and in the image of God. The couple existed without knowledge of sin; however, writers observed a flaw with Eve's intellectual abilities. Franciscan scholastic and theologian St. Bonaventure (2005:105) did not deviate from previous writers, but proposed these critical comments regarding the woman, projecting her as a transmitter of evil deeds: 'after the woman was led astray, she enticed the man, who similarly turned to the outer book and to transitory goods' (Bonaventure 2005:105). He and others use the words entice or beguile, which connote the femme fatale psychology. Therefore, the woman employs her innate charm and external beauty to influence the man.

Luther (1958), a towering figure of the Protestant Reformation, wrote that women possess a slightly lower status than the man:

For the woman appears to be a somewhat different being from the man, having different members and a much weaker nature. Although Eve was a most extraordinary creature - similar to Adam so far as the image of God is concerned, that is, in justice, wisdom, and happiness - she was nevertheless a woman. For as the sun is more excellent than the moon so the woman although she was a most beautiful work of God, nevertheless, was not the equal of the male in glory and prestige. (pp. 68-69)

According to Luther's interpretation, as Eve lacked the gravitas of Adam, she was more susceptible to the cunning schemes of the serpent who deceived her. Her beauty was superior to Adam's, however, which allowed her to influence his behaviour. Again, the empowering beauty of the woman captivated the man and rendered him powerless to flee from the woman's effect.

\section{Nineteenth century to modern}

The assignment of guilt to the woman for the fall of humankind continued through the 19th century. Theologians noted the passive leadership of the man and the seductive nature of the woman. Both the lack of strength of conviction by the man and the allurement of the woman continue the ferme fatale theme. Franz Delitzsch (2001) opined:

$[H]$ e whose existence in the Divine image preceded that of the woman remains at first passive in the transaction against God, and then become the follower of his wife in sin. The woman who was the first seduced lost her human dignity to the serpent, and the man next seduced, lost over and above his manly dignity to the woman. (p. 155)

The sentiments were pervasive as Lange (1873:251) affirmed, '[t]he first female sinner becomes, after Serpent's fashion, the first temptress'.

Brown et al. (1968:13) echoed, '[t]he woman is tempted and falls first; she then tempts man'. The order of punishment serves as an indicator for the severity of the transgression in the Garden of Eden. The serpent is punished first for his excessive offense of manipulating the woman. The woman is second because of her iniquity. Many interpreters reason that the woman deserved a scathing analysis as she is the culprit, the temptress, who enticed her husband into sin, guilt and shame with her beauty (cf. Brown et al. 1968:13; Krahmer 2000:304-327). The serpent approached the woman because her physical attractiveness would allow her to enslave the man through sexual desires according to McKenzie (1954:570). The attractiveness of the woman not only ensnared the man but also would enslave herself to a man as a result of her choice (McKenzie 1954:570). Furthermore, Krahmer (2002:4) suggested that Eve lacked the wisdom to utilise her beauty and flattery to cajole the man towards their Creator. Instead, she seduced Adam to commit sin because she lacked the knowledge and rational wisdom, thereby possessing a lust for worldly goods.

In sum, many commentators over the centuries argue that the woman lured the man into sin; she initiated the process that led to the demise of humankind. According to the writers who blame the woman, nothing can remove the guilt she incurred and deserved in the Garden of Eden. 


\section{Feminist perspective on Genesis 3}

It is important to note that feminism has existed for centuries, and to provide a succinct definition is difficult. In Helpmates, Harlots, and Heroes, Bellis (1994) argued:

[F]eminism has a long history. No one definition would satisfy all feminists; rather a range of understandings is needed. Nevertheless, feminism may be broadly defined as a point of view in which women are understood to be fully human and entitled to equal rights and privileges. In no sense can they be considered subordinate or inferior. (p. 6)

The definition expands as Schroer (2003) articulated:

$[A]$ ccording to Schüssler Fiorenza, Feminism strives to expose veiled and open discrimination of women within the kyriarchal ${ }^{6}$ pyramid as well as in the intrinsic ideologies that sustain it, and fights for the recognition of the complete rights of half of humanity. (p. 2) ${ }^{7}$

The previous definitions find support in The Woman's Bible by Stanton (1895), who suggests:

From the inauguration of the movement for woman's emancipation the Bible has been used to hold her in the 'divinely ordained sphere', prescribed in the Old and New Testaments. The canon and civil law; church and state; priests and legislators; all political parties and religious denominations have alike taught that woman was made after man, of man, and for man, an inferior being, subject to man. Creeds, codes, Scriptures and statutes, are all based on this idea. The fashions, forms, ceremonies and customs of society, church ordinances and discipline all grow out of this idea. (n.p.)

For decades, feminists sought to eradicate the oppressive message of scripture that expanded to every sector of the society. Stanton (1895) continues by noting:

The Bible teaches that woman brought sin and death into the world, that she precipitated the fall of the race, that she was arraigned before the judgment seat of Heaven, tried, condemned and sentenced. Marriage for her was to be a condition of bondage, maternity a period of suffering and anguish, and in silence and subjection, she was to play the role of a dependent on man's bounty for all her material wants, and for all the information she might desire on the vital questions of the hour, she was commanded to ask her husband at home. Here is the Bible position of woman briefly summed up. (n.p.)

In essence, patrialistic scholars believed that women were the catalyst for the sin and death that exists, and their punishment is subjection to their husband. The perceived oppressive message of the Bible led feminists to offer varied hermeneutical approaches to the Hebrew Bible.

\section{Denial, depatriarchal and deconstruction of the fall}

Three notable interpretations of the fall are presented:

Firstly, there is a complete exoneration of the woman by denying the occurrence of a fall.

6.For an explanation of kyriarchal pyramid see Fiorenza (2017).

7.Schroer quotes a definition from Elizabeth Schüssler Fiorenza during an international dialogue on feminist biblical hermeneutics.
Meyers (1993:127) is dismissive of the fall of humanity or the sin of the woman. Instead, she recommends other salient themes that manifest from the text. By reducing Genesis 3 to a conversation about disobedience and its consequences is an 'oversimplification of a rich and powerful narrative' (Meyers 1993:127). She suggests that the concept of a fall is derived from traditional Midrash theology and Orphic thought that was prevalent in the eastern Mediterranean world in late antiquity (Meyers 1993:127). ${ }^{8}$ Moreover, she explains, the lack of an explicit reference to sin in the narrative, the strong aetiological flavour of the Eden story and the absence of the vocabulary of $\sin$ are evidence for reconsidering the interpretation of the passage. The lack of sin terminology absolves the woman of guilt. Denial of a fall persists outside feminist theology as well.

Herbert Haag (1969a:19) questioned the doctrine of original sin in his book 'Is Original Sin in Scripture?' He sought to dismantle the interpretation of Genesis 3 by suggesting, ' $[t]$ he doctrine of original sin is not found in any of the writings of the Old Testament. It is certainly not in chapters one to three of Genesis'. He concludes in Der Urstand nach dem Zeugnis der Bibel, '[t]he present conceptions of catholic and evangelical dogmatics, according to which the primeval state was a temporal phase at the beginning of human history ... entsprechen nicht der Bibel' do not occur in the Bible (Haag 1969b:267). ${ }^{9}$ Haag maintained that the anthropology of the Christian tradition of the West is rooted in the Augustinian tradition derived from the Apostle Paul's arguments in the Book of Romans. Therefore, original sin does not have its origin in the Genesis narratives. Paul Tillich (1957) noted that the concept of a fall solves:

$[A]$ rather difficult problem in a simple way ... Adam before the Fall exists in a state of potentiality ... The notion of a moment in time in which man and nature were changed from good to evil is absurd, and it has no foundation in experience or revelation. (pp. 40-41)

Although select writers deny the fall, the Bible consistently affirms the sin by Eve (Gn 3:7-24; 1 Tim 2:13-14). Also, humankind is 'shaped in iniquity and conceived in sin' (Psalm 51:5) without the capacity to deliver themselves, which is a total depraved condition (Gn 6:8; Ps 119:176; Is $53: 6-7 ; 55: 7)$.

Genesis 3 marks the transition from a state of perfection to a perplexing conscience filled with animus, anxiety and antagonism. Scripture has been supernaturally preserved and cannot fulfil the classification of myth. The Bible repetitively characterises humanity as fallen, dwelling in a state of sin, without the capacity to deliver themselves, which is total depravity (Gn 6:8; Ps 119:176; Is 53:6-7; 55:7).

Secondly, there is a depatriarchal view of the biblical text. Trible (1978:xvi, 1984:1-6) employed this method by defining the positive text as 'counterliterature' and the 8.In the 'Serpent Was Wiser', Hanson (1972:41-42) expounds on the Orphic presence in Genesis 3.

9.For a complete presentation, see Haag (1968:385-404). 
negative text as 'text of terror'. She posits, 'using feminist hermeneutics, I have tried to recover old treasures and discover a new one in the household of faith' (Trible 1978:xvi). By employing a feminist hermeneutic to the Hebrew Bible, she can depatriarchalise the text by speculating the following (Trible 1973):

[L]et a female speculate. If the serpent is "more subtle" than its fellow creatures, the woman is more appealing than her husband. Throughout the myth, she is the more intelligent one, the more aggressive one and the one with greater sensibilities. (pp. 30-48) $)^{10}$

Whereas the patriarchal view may drastically reduce the acumen of the woman, the matriarchal view accelerates Eve's intellectual capabilities. Now Eve stands equal or superior to Adam, which is why the serpent is singularly focused on her. In essence, the depatriarchal view extends beyond the biblical text to the idea of God being Father. The feminists seek to eradicate the masculine presence period to satisfy their hermeneutics.

Thirdly, there is a deconstructionist ${ }^{11}$ approach to the fall. Within the three approaches, the deconstructionist offers the most radical departure from an author-text towards a reader-text interpretation. The reader determines the meaning apart from the author's original historical context or intent. Select commentators appear to approach the Genesis 3 narrative with a deconstructionist mindset that is a departure from historical and traditional interpretations (Fuchs 2008:45-65; Gellman 2006:319-335; Scholz 2010:9-32). A few interpretations of Genesis 3 that highlight deconstructionist scepticism include the following: the seduction of Adam by Eve is noble, Genesis 1-11 is characterised as myth and the definition for a femme fatale is recast to present the woman as a heroine.

\section{Noble seduction}

Bechtel (1993:111) posited that the reader should affirm the woman in the role of a seductress since the Hebrew Bible does not prohibit or negatively address the matter between husband and wife. Seducing the husband is not adverse, rather it leads to reproduction and the continuation of the legacy. Seduction by 'foreign or strange women' is forbidden because of the advancement of other nations of people (Bechtel 1993:111). Bechtel contends God tempted or seduced 'Adam' by presenting the woman to him, so how could seduction receive an adverse connotation if God is the originator of seduction? Bechtel analysis ignores the essential message of the narrative. The seduction of Adam and the transgression by the primordial couple transferred an atrocious legacy for humankind of fear, guilt and shame that

10.For further consideration of feminist interpretation of Genesis, see Susanne Scholz (2010:9-32) and Phyllis Bird (1983:275-279).

11.Deconstruction has philosophical roots in the 'masters of suspicion' (Marx Nietzsche and Freud). It questions traditional assumption regarding language, asks readers to eliminate the metaphyical and argues that meaning is defined by the readers to eliminate the metaphysical and argues that meaning is defined by the eader who should redefine words or create new word constructions, etymology, only refer to other words and nothing or no one may offer a basis for the meanin of a text (e.g. God, author and speaker). Deconstruction is a unique form of scepticism that seek to remove authority or meaning from a text (cf. Atkins 1983; Culler 1982; Dole 2020; Ward 2004). extends beyond human recourse. Additionally, God's

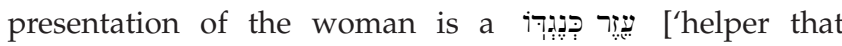
corresponds'] to the man. An [ִיזר ['helper'] signifies value; as the noun is often used to refer predominantly to God's divine assistance and the ability to deliver his people (Ex 18:4; Ps 70:5). Harman (1997:376) notes that [shield] to emphasise protection provided by a warrior in the context of battle (Dt 33:29; Pss 33:20; 89:18-19; 115:9-11). What is missed by Betchel's interpretation is the helper, like God, serves as a deliverer of the man. The woman functions in a diminished capacity from God; nevertheless, she functions as a helper by shielding the man from potential misfortune.

\section{Genesis 3 as myth}

Leeming (2015:1-2) explained that myths are stories about gods and heroes who are embraced as true by select groups and untrue by others. The stories do not have a particular origin from an individual; however, they are held as sacred by family, clan, tribe, religion or nation. Applying this definition of myth restricts the scope of the fall. The seduction by Eve, if it occurred, only has implications for individuals embracing the Hebrew Bible as truth.

In 1902, before the Deutsche Orient-Gesellschaft in Berlin, Friedrich Delitzsch presented his infamous paper titled, 'Babel und Bibel'. He argued that significant portions of the content in Genesis were plagiarised from Babylonian mythology and reworked by anonymous Hebrew authors during the Babylonian Exile. ${ }^{12}$ In 1907, he published Mehr Licht [More Light] escalating the rhetoric for a Babylonian presence within the Bible. Loader (2003:309-321) noted that Bultmann (1960:1278-1282) followed Delitzsch and intensified the belief of myths in the Bible by imposing a demythologising programme on the worldview of early Christianity. Each publication provides credence for varied interpretations or complete denial of Eve's role as a femme fatale.

\section{Redefining femme fatale}

In an attempt to absolve the woman of luring the man into sin, Edwards (2010) suggested redefining Eve's role because Genesis 3 allows us to see an archetypical femme fatale. She (Edwards 2010) provides the following definition:

[A] knowing woman, skilled at telling stories, irresistibly attractive to an immature man, whom she leads into the difficult and dangerous possibility of growing up, a possibility he first embraces and then rejects, with disastrous consequences for himself and for her. It is a redefinition that heightens rather than diminishes the allure of the femme fatale. (pp. 43-44)

The alternative characterisation by Edwards casts Eve as a superior sanctifier of the 'immature' instead of a sneaky seducer. A personal aversion to a text, however, does not grant an interpreter the liberty to redefine terms that alter the original author's intent.

12.See Delitzsch (1903). In 1904 Delitzsch responded to his critic's arguments by publishing Babel und Bibel: Ein Ruckblick und Ausblick [Babylon and the Bible: A Look Back and a Look Forward] 
In sum, writers who seek to excuse or recast the woman abandon their literary and interpretive duty. Feminists are especially guilty of this offence because of their allegiance to an ideology that ignores or redefines anything that appears to subordinate women to men. In an effort to relinquish the years of real or perceived oppression, feminists, to their detriment and that of men, deny or re-appropriate literary texts. In essence, the feminist ideology is a continual replication of the fall on a micro-level.

The biblical account of the fall describes the woman blaming the serpent for her rebellion. The woman does not accept responsibility for her fraudulent actions. She maliciously ate the fruit. Feminists blame a patriarchal interpretation, the biblical author(s) and ultimately God for the woman's role. By shifting the responsibility and focus, feminists refuse to accept their mother and father sinned. The reinterpretation of the biblical narrative by feminist does not compel successive generations to conform to the divine commands of a holy God. Both the man and the woman transgressed God's moral law and endured the consequences. The books and articles written from a feminist perspective shift the infraction by Eve. Therefore, feminists replicate the rebellion of their mother Eve.

In 'Blaming Eve Alone: Translation, Omission, and Implications of ب̣ in Genesis 3:6b', Parker $(2013: 729,733)$ noted that the

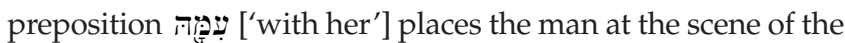
events between the serpent and the woman. Correctly, she argues that grammatically the preposition provides critical evidence for theologians who are seeking to isolate Eve and blame her for the fatal act of disobedience. It is incumbent on translators to reflect the man's presence with the woman through their translations and not excuse the man, whilst condemning the woman. In the final analysis, however, the man is culpable, and Parker acknowledges that the woman did not fulfil her divinely created role as the helper.

All three views, the denial of the fall, the depatriarchalising of the biblical narrative and the deconstructionist interpretation disregard the authoritative meaning of the biblical text.

The biblical presentation of the man and woman's disobedience provides a factual presentation of events that occurred and should be received as an authoritative source of truth. Unambiguously, the Bible delineates the creation and fall of humanity. Why would God in his providence permit the biblical author to record a fictitious narrative with spurious claims? The facts are simple and unavoidable, but the desire for fanciful analysis or the attempt to justify a presupposition abounds amongst select groups. By reinterpreting the fall narrative, feminists offer a singular perspective on biblical interpretation. The unwillingness of interpreters to accept the biblical narrative as authoritative presents a challenge. If an interpreter does not view the Bible as the word of God, then any explanation is permissible. Many interpreters function like the primordial couple and desire alternative explanations of the Biblical narrative, which exceed God's divine parameters. The Bible states that
God created the man and woman in the Imago Dei and both rebelled (Gn 1:26-28; 3:7-24).

Consideration for the literary features of the biblical text and the historical and cultural context is ignored. What emerges from the feminist interpretations are personal predispositions that reveal a psychological portrait of the writer and the societal inclination. The final section analyses the fall narrative within its literary context.

\section{The setting and snakes of creation}

The setting for Genesis 1-3 is the creation account of humankind by God, who placed them in the Garden of Eden to serve as his vice-regents. Chapter 3 of Genesis details the introduction of sin into creation through the primaeval couple's transgression against God. Sin did not exist in the Garden of Eden or in the psychology of the cast of characters in the narrative (i.e. God, man, woman and serpent), but that did not prohibit the woman from becoming the first femme fatale. The plot surfaces when the serpent initiates a dialogue with the woman. Snakes are embedded within the Ancient Near Eastern literature as alternatively sinister or wise creatures.

The Gilgamesh Epic characterises snakes as duplicitous entities waiting to launch their menacing attacks on the unsuspecting. Gilgamesh tells Urshanabi that he has retrieved a plant with the capacity to restore youth for himself and the elderly, but on his journey to Uruk a snake intervened ${ }^{13}$ (Sanders n.d.):

Gilgamesh saw a well of cool water and he went down and bathed; but deep in the pool there was lying a serpent, and the serpent sensed the sweetness of the flower. It rose out of the water and snatched it away, and immediately it sloughed its skin and returned to the well. (p. 22)

The Genesis creation account differs from the Gilgamesh epic, but the themes of the serpent, plant and the loss of eternal life are present in both. Both accounts characterise the serpent as a sinister being to be avoided. In contrast, Joines (1974:1-11) calls attention to the ancient Orient where snakes were symbols of wisdom and life. The West Semitic system believed that snakes were a phallic animal associated with fertility cults based on images of naked or semi-naked goddesses of fertility accompanied by snakes (Münnich 2008:42). ${ }^{14}$ Images appear from Ugarit, Egyptian and Canaanite art depicting Semitic goddesses holding snakes in their hands, or the snakes entwined about them (Münnich 2008:43). Snakes are connected to the storm god and with one of the most dangerous demons, Lamashtu (also written as Lamaštu $)^{15}$ who appears in her homeland of Mesopotamia and in Syro-Canaan in iconography holding venomous snakes in her hands (Münnich 2008:42). Whether culturally sinister or wise, the snake will seduce the woman in Genesis 3 and she will seduce the man.

13.See http://www.aina.org/books/eog/eog.pdf (Sanders n.d.).

14.Münnich recommends these sources for further study: Buchholz (2000) and Joines (1975).

15.See also http://www.ancientneareast.net/mesopotamian-religion/lamastu-lamashtu/. 


\section{The voice: Obedience and authority}

Genesis 3:6 and 17 offers answers for the woman's influence on the man. The seminal passage, however, that substantiates the woman's role as a femme fatale occurs in

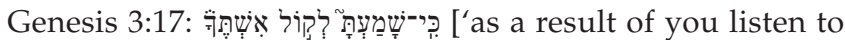
the voice of your wife']. Several commentators avoid commenting on the passage (Hamilton 1990:202-204; Longman 2016:70-73; O'Connor 2018:65-67; Sarna 1989:28; Westermann 1994:263-265). ${ }^{16}$

Firstly, the woman demonstrates a leadership role by engaging with the serpent (Gn 3:1-6). Her actions suggest the ability to act as the authorised representative and leader of the couple. Secondly, the woman portrays knowledge of the circumstances beyond the man. By deciphering nuances of the fruit (good for food, delight to the eyes and making one wise; Gn 3:6), the woman assumed that her knowledge is sufficient to make an informed decision. Thirdly, the woman is seduced by the serpent, and then she entices the man with words to eat the fruit. Through persuasive words and her radiant beauty, the woman convinced her husband to transgress God's command (Gn 3:6, 17). It is important to note that the woman's beauty is inferred from the 11 affirmations that everything God created was 'טic' ('good, beautiful, sweet') (Gn 1:4, 10, 12, 18, 21, 25, 31; 2:9, 12, 17, 18). The continual emphasis on the creation being 'good' reflects a level of beauty and pristine appearance in God's creation. Certainly, the eye-catching attraction extends to the man and woman. Höver-Johag (2011:303) noted as late as the Christian era, Palmyrene and Nabatean graffiti used 'טוֹ 'ט ' in combination with other root forms to refer the 'beauty' and 'excellence' of a woman. The aforementioned action by the woman in the Garden of Eden (leadership, knowledge and seductive words) are the quintessential elements of the femme fatale. The woman used leadership, knowledge, beauty and persuasion to entice the man to eat the fruit.

Although the narratives are not parallel because of the preand post-fall condition of humanity, a similar scenario occurs in Judges 14:15 and 16:5. In Genesis 3, the events transpire apart from a sinful disposition. Every interaction thereafter includes a sinful nature that cannot honour God. Nevertheless, salient features emerge from the Judges' narratives that are worth noting.

The Philistines demand Samson's wife to your husband' $]^{17}$ and, therefore, he would reveal the riddle.

16.0'Connor (2018:66-67) avoided Genesis $3: 17$, the seminal passage that explain God's reason for punishing Adam and Eve. Nevertheless, she blames patriarchy no the woman, serpent or God for the social conditions: 'patriarchal thinking today continues around the globe and in the United States. It is deeply intertwined with racism and classism and all forms of social organization that grant authority and privilege to the few. Typically, patriarchal thinking values men over women, whites over people of color, and rich over poor. Although global challenges to these entrenched ways of living are emerging, these systems still prevail in both blatant and subtle ways' (O'Connor 2018:66-67).

17.Mosis (2011:162-172) suggested the condition described by פתה is never itself a desirable goal or one in which a person should abide; even though no moral or religious value judgement inheres in פתת itself, it does nonetheless always imply a lack or shortcoming. The word is associated more with the notion of inexperienced naive youth lacking the necessary maturity and understanding that could lead to death as a result of being sexually promiscuous (cf. $\operatorname{Pr} 1: 4 ; 7: 7$ ).
The woman is beautiful because Samson says, '[g]et her for me, for she looks good to me' (Jdg 14:3). Chisholm (2013:409) observes, 'Samson seems to possess great cunning, but he overlooked two important facts - the Philistine's ingenuity and, more importantly, his own vulnerability to female charm'. His susceptibility made him reveal the riddle (Jdg 14:15; cf. 16:5). ${ }^{18}$ The same occurs with Delilah regarding Samson's strength but at the expense of his life (cf. 16:5-31). One can assume Delilah is beautiful, as Samson places emphasis on the physical appearance of his wife in Judges 14.

In a second attempt to rid themselves of Samson, the Philistines rulers command Delilah to ג'Entice him! See where his great strength lies and how we may overpower him and humiliate him'], the narrative explains the tactic she employed (Jdg 16:5).

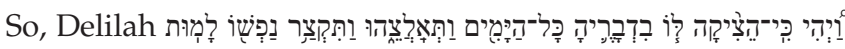
[' $[P]$ ressed him daily with her words and urged him that his soul was annoyed to death'] (Jdg 16:16). The incessant nagging with her words exasperated his heart (Webb 2012:404). Webb (2012:404) further noted that the same reference is used of

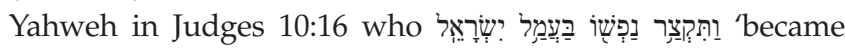
exasperated with Israel's misery' and finally gave them their request for deliverance from the Ammonites. The difference is that Samson gave his heart secret to Delilah without knowing she would betray him. Likewise, it was the words of the woman that enticed the man in the Garden of Eden to eat the forbidden fruit. Genesis 3 says:

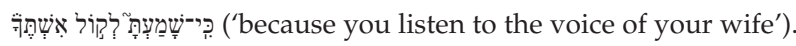
The use of 'voice' is metonymy for obedience and authority. Both Adam and Samson were enticed and pressed with words that led them to rebel against God's divine prohibitions by femme fatales. The men are guilty for acquiescing and receive a penalty for their actions, but the women receive their labels for their roles. (v. 17)

\section{In summary}

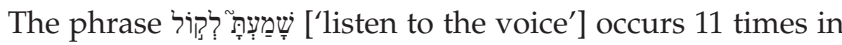
the Old Testament denoting obedience or listening to words (Gn 3:17; Ex 3:18; 4:8; 15:26; Jdg 2:20; 1 Sm 2:25; 15:1; 28:23; $1 \mathrm{Kg}$ 20:25; Jr 18:19; Ps 58:5[6]). Three distinctions are worth noting regarding the phrase 'listen to the voice':

- The phrase references obeying a command or hearing what occurred without the consideration for one being a superior or inferior. King Saul obeyed his servants and the witch at Endor (1 Sm 28:23; cf. the servant advises the King of Aram $1 \mathrm{Kg}$ 20:25; Gn 3:17). Jeremiah asked the Lord to 'hear the words of his enemies' (Jr 18:19).

- The phrase occurs with spoken words, written commands and signs. Eli's sons did not listen to his wise counsel

18.In Judges 14:15 and 16:5, the wife and Delilah are commanded to 'ngentice' or 'trick' Samson. The verbs stem in both passages are pile with a factitive use and an imperative conjugation. The intensity of the command by the Philistine rulers is reflected by their threat: 'or we will burn you and your father's house with fire' (Jdg 14:15). 
(1 Sm 2:25; cf. 15:1), Israel transgressed God's written covenant (Jdg 2:20; cf. Ex 15:26) and the elders in Israel and slaves in Egypt had to decide to obey the miraculous signs performed by Moses (Ex 3:18; 4:8).

- The phrase notes general obedience that may occur between humankind and animals. In Psalm 58:5[6], 'the cobra does not obey the snake charmer or the skillful caster of spells'.

Repeatedly, the Old Testament uses the idiom for general obedience. The reality is seen when the man eats the fruit as a result of obeying the voice of his wife, and God, therefore, made eating adverse through thorns, thistles and sweat (Gn 3:17-18). The man receives a more severe punishment because the role granted to him by God as the first created ('and only' omitted) thing to embody the image and likeness of God (Gn 1:26-28; 2:7, 18-25). The narrative demonstrates that the man failed as a leader and husband by deferring to the voice of his wife over the voice of the Lord (Gn 2:16-17).

Although there is a reluctance to identify Eve as the first femme fatale, that is her identity at this moment in the Genesis narrative. The primordial woman's distinct qualities and behaviour epitomise the original definition of a femme fatale.

\section{Acknowledgements Competing interests}

The author declares that he has no financial or personal relationships that may have inappropriately influenced him in writing this research article.

\section{Author's contribution}

R.C. is the sole author of this research article.

\section{Ethical consideration}

This article followed all ethical standards for research without direct contact with human or animal subjects.

\section{Funding information}

This research received no specific grant from any funding agency in the public, commercial, or not-for-profit sectors.

\section{Data availability}

Data sharing is not applicable to this article as no new data were created or analysed in this study.

\section{Disclaimer}

The views and opinions expressed in this article are those of the author and does not necessarily reflect the official policy or position of any affiliated agency of the author.

\section{References}

Archer, G.L., 1997, A survey of the Old Testament introduction, Moody Press, Chicago, IL. Atkins, D.G., 1983, Reading deconstruction/deconstructive reading, University of Kentucky, Lexington, $\mathrm{KY}$.

Augustine, 2009, The city of God, transl. M. Dods, Hendrickson Publishers, Peabody, MA.

Augustine \& Taylor, J.H., 1982, The literal meaning of Genesis, (Ancient Christian writers, no. 41-42), Newman Press, New York, NY.

Bailey, J.A., 1970, 'Initiation and the primal woman in Gilgamesh and Genesis 2-3', Journal of Biblical Literature 89(2), 137-150. https://doi.org/10.2307/3263044

Bechtel, L.M., 1993, 'Rethinking the interpretation of Genesis 2:4B-3:24', in A. Brenner (ed.), A feminist companion to Genesis, pp. 77-117, Sheffield Academic Press, Sheffield.

Bellis, A.O., 1994, Helpmates, harlots, and heroes: Women's stories in the Hebrew Bible, Westminster John Knox Press, Louisville, KY.

Bird, P., 1983, 'Images of women in the Old Testament', in N.K. Gottwald (ed.), The Bible and liberation: Political and social hermeneutics, pp. 275-279, Orbis, Maryknoll, NY.

Bonaventure, 2005, Works of Saint Bonaventure, Breviloquium, transl. D.V. Monti, vol. 3/3, St. Bonaventure, Franciscan Institute Publications, New York, NY.

Brown, R.E., Bea, A.C., Fitzmyer, J.A. \& Murphy, R.E., 1968, The Jerome biblical commentary, Prentice-Hall, Englewood Cliffs, NJ.

Buchholz, H.G., 2000, 'Furcht vor Schlangen und Umgang mit Schlangen in Altsyrien, Altkypros und dem Umfeld', Ugarit-Forschungen 32, 37-168.

Bultmann, R., 1960, 'Mythos und Mythologie IV: Im Neuen Testament. 3. Aufl. (= 2. Aufl.)', RGG 4, 1278-1282.

Charlesworth, J.H., 2010, The good and evil serpent: How a universal symbol became Christianized, Yale University Press, New Haven, CT.

Charlesworth, J.H. (ed.), 2011, The Old Testament Pseudepigrapha, vol. 1, Hendrickson Publishers, Peabody, MA.

Chisholm, R.B., 2013, A commentary on Judges and Ruth, Kregel, Grand Rapids, MI.

Chrysostom, J., 1979, A select library of the Nicene and post-Nicene fathers of the Christian Church, 1st series, vol. 13, Eerdmans Publishing, Grand Rapids, MI.

Collins, J.J., 2000, Between Athens and Jerusalem: Jewish identity in the Hellenistic diaspora, 2 nd edn., William B. Eerdmans, Grand Rapids, MI.

Culler, J., 1982, On deconstruction: Theory and criticism after structuralism, Cornell University, Ithaca, NY.

Delcor, M., 1989, 'The Apocrypha and Pseudepigrapha of the Hellenistic period', in W.D. Davies \& L. Finkelstein (eds.), The Cambridge history of Judaism, vol. 2, pp. 409-503, Cambridge University Press, Cambridge.

Delitzsch, F., 1903, Babel und Bibel: ein Vortrag, 3. Durchgesehene Aufl edn., J.C. Hinrichs, Leipzig.

Delitzsch, F., 2001, A new commentary on Genesis, transl. S. Taylor, vol. 1, Wipf and Stock Publishers, Eugene, OR.

Didymus, 2016, Commentary on Genesis, transl. R.C. Hill, vol. 132, Catholic University of America Press, Washington, DC.

Dole, A., 2020, 'Reframing the masters of suspicion: Marx, Nietzsche, and Freud', Journal of the American Academy of Religion 88(2), 615-618. https://doi. org/10.1093/jaarel/lfz096

Edwards, K.L., 2010, 'The mother of all femme fatales: Eve as temptress in Genesis 3', in H. Hanson \& C. O'Rawe (eds.), The femme fatale: Images, histories, contexts, pp. 35-44, Palgrave Macmillan, London.

Fiorenza, E.S., 2017, Congress of wo/men: Religion, gender, and Kyriarchal power, Dog Ear Publishing, Indianapolis, IN.

Fuchs, E., 2008, 'Reclaiming the Hebrew bible for women: The neoliberal turn in contemporary feminist scholarship', Journal of Feminist Studies in Religion 24(2), 45-65. https://doi.org/10.2979/FSR.2008.24.2.45

Gaines, J.H., 2019, 'Lilith: Seductress, heroine or murderer', Bible Review 17(5), viewed 03 April 2020, from https://www.biblicalarchaeology.org/daily/peoplecultures-inthe-bible/people-in-the-bible/lilith/\#note08r.

Gaster, T.H., 1969, Myth, legend, and custom in the old testament, Harper \& Row, New York, NY.

Gellman, J.I., 2006, 'Gender and sexuality in the garden of Eden', Theology \& Sexuality $12(3), 319-335$

Haag, H., 1968, 'Der "Urstand" nach dem Zeugnis der Bible', Theologische Quartalschrift 148(4), 385-404.

Haag, H., 1969a, Is original sin in scripture? Sheed and Ward, New York, NY.

Haag, H., 1969b, 'Zeitschrift für die alttestamentliche wissenschaft', Publons 81(2), 145-286.

Hamilton, V.P., 1990, The book of Genesis: Chapters 1-17, Eerdmans, Grand Rapids, MI. Hanson, R.S., 1972, The serpent was wiser: A new look at genesis 1-11, Augsburg Publishing House, Minneapolis, MN.

Harman, A.M., 1997, 'עיר', in W. Van Gemeren (ed.), A guide to Old Testament theology and exegesis: The introductory articles from the new international dictionary of Old Testament theology and exegesis, pp. 376-377, Zondervan, Grand Rapids, Ml. 
Helyer, L.R., 2002, Exploring Jewish literature of the second temple period: A guide for New Testament students, InterVarsity, Downers Grove, IL.

Höver-Johag, I., 2011, 'טוֹ', in G.J. Botterweck, H. Ringgren, J.T. Willis, D. Green \& D.W. Stott (eds.), Theological dictionary of the Old Testament, pp. 296-317, Eerdmans, Grand Rapids, MI.

Joines, K.R., 1974, Serpent symbolism in the old testament: A linguistic, archaeological, and literary study, Haddonfield House, Haddonfield, NJ.

Joines, K.R., 1975, 'The serpent in Genesis 3', Zeitschrift für die alttestamentliche Wissenschaft 87, 1-11.

Krahmer, S.M., 2002, 'Adam, eve, and original sin in the works of Bernard of Clairvaux', Cistercian Studies Quarterly 37(1), 3-12.

Lange, J.P., 1873, A commentary on the Holy Scriptures, transl. P. Schaff, Scribner, Armstrong, \& Co., New York, NY.

Leeming, D.A., 2015, The handy mythology answer book, Visible Ink Press, Canton, MI.

Loader, J.A., 2003, 'The primeval narrative as a literary myth', Old Testament Essays $16(2), 309-321$.

Longman, T., 2016, Genesis, Zondervan, Grand Rapids, MI.

Luther, M., 1958, Luther's works. Vol. 1: Lectures on Genesis: Chapters 1-5, in J. Pelikan et al. (eds.), Concordia Publishing House, Saint Louis, MO.

McKenzie, J.L., 1954, 'The literary character of Genesis 2-3', Theological Studies 15(4), 542-572. https://doi.org/10.1177/004056395401500402

Meyers, C.L., 1993, Gender roles and Genesis 3:16 revisited in the feminist companion to Genesis, A. Brenner (ed.), FCB 2, Sheffield Academic Press, Sheffield.

Mosis, R., 2011, 'פתה', in G.J. Botterweck, H. Ringgren, J.T. Willis, D. Green \& D.W. Stott (eds.), Theological dictionary of the Old Testament, 162-172, Eerdmans, Grand Rapids, MI.

Münnich, M., 2008, 'The cult of bronze serpents in ancient Canaan and Israel', in B.J. Schwartz, A. Melamed \& A. Shemesh (eds.), Iggud: Selected essays in Jewish studies. Vol. 1. The Bible and its world, Rabbinic literature and Jewish law, and studies. Vol. 1. The Bible and its World, Rabbinic literature and Jewish law, and
Jewish thought, pp. 39-56, World Union of Jewish Studies Jerusalem, Jerusalem.

Nazianzen, G., Schaff, P. \& Wace, H., 1994, A select library of the Nicene and postNicene fathers of the Christian church [2nd series], vol. 7, Hendrickson Publishing, Peabody, MA.

O'Connor, K.M., 2018, Genesis, Smyth \& Helwys Bible commentary 1, Smyth \& Helwys, Macon, GA.
Parker, J.F., 2013, 'Blaming Eve alone: Translation, omission, and implications of Genesis 3:6b', Journal of Biblical Literature 132(4), 729-747. https://doi. org/10.1353/jbl.2013.0050

Phelan, M.W.J., 2005, The inspiration of the Pentateuch or, the Graf-Wellhausen fallacy, Two Edge Sword, Waterlooville.

Phipps, W., 1989, Genesis and gender: Biblical myths of sexuality and their cultural impact, Praeger, New York, NY.

Sanders, N.K., n.d., 'The epic of Gilgamesh', Assyrian International News Agency Books Online, viewed 11 May 2020, from http://www.aina.org/books/eog/eog.pdf.

Sarna, N.M., 1989, Genesis: Be-reshit: The traditional Hebrew text with new JPS translation, The JPS Torah commentary, Jewish Publication Society, Philadelphia, PA.

Scholz, S., 2010, 'A third kind of feminist reading: Toward a feminist sociology of biblical hermeneutics', Currents in Biblical Research 9(1), 9-32. https://doi. org/10.1177/1476993X10364969

Schroer, S., 2003, "We will know each other by our fruit": Feminist exegesis and the hermeneutics of liberation', in S. Schroer \& S. Bietenhard (eds.), Feminist interpretation of the Bible and the Hermeneutics of liberation, pp. 1-17, Sheffield Academic Press, Sheffield.

Stanton, E.C., 1895, The woman's Bible, Coalition on Women and Religion, Seattle, WA, viewed 07 June 2020, from http://www.gutenberg.org/cache/epub/9880/ pg9880-images.html.

Stern, D. \& Mirsky, M.J., 1998, Rabbinic fantasies, Yale University Press, New Haven, CT

Tillich, P., 1957, Systematic theology, vol. 2, University of Chicago Press, Chicago, IL.

Trible, P., 1973, 'Depatriarchalizing in the biblical interpretation', Journal of the American Academy of Religion 41(1), 30-48.

Trible, P., 1978, God and the rhetoric of sexuality, Fortress Press, Philadelphia, PA.

Trible, P., 1984, Texts of terror literary-feminist reading of biblical narrative, Fortress Press, Philadelphia, PA.

Ward, G.S., 2004, Barth, Derrida and the language of theology, Cambridge University Press, Cambridge.

Webb, B.G., 2012, The book of judges, William B. Eerdmans, Grand Rapids, MI.

Westermann, C., 1994. Genesis 1-11, transl. J. Scullion, Augsburg, Minneapolis, MN. 